\title{
巻き取り過程におけるウェブの横ずれとロール側面形状のシミュレーション （層ずれ，湾弧，テレスコープの発生過程）
}

\author{
矢鍋 重夫*1，永澤 茂*2，Pusit MITSOMWANG*3

\begin{abstract}
Lateral shift of web and edge shape of roll in winding process simulated by FEM (Development of web lateral shift, roll curved edge, and telescoping)
\end{abstract}

\author{
Shigeo YANABE ${ }^{* 1}$, Shigeru NAGASAWA ${ }^{* 2}$ and Pusit MITSOMWANG ${ }^{* 3}$

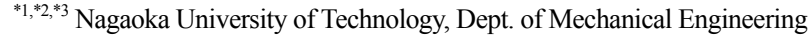 \\ 1603-1 Kamitomiokamachi, Nagaoka-shi, Niigata 940-2188, Japan
}

Received 25 August 2014

\begin{abstract}
Various kinds of wound roll defects such as telescoping, dishing, starring, and wrinkles often appear in many manufacturing lines of web handling. In order to investigate how the dishing or telescoping is developed and to get fundamental knowledge of these roll defects, several web winding processes are simulated by using a simple three dimensional FEM model which is composed of an isotropic web and a rigid core. In the simulation, effects of core inclination, unbalanced web tension, and constraint of lateral displacement of the web end on both a lateral shift of web and an edge shape of wound roll are investigated. The results show that (1) when the web is wound around the inclined core, the web shifts at first to the side where the web becomes loose due to the core inclination, and then it returns almost to the original position, if the web end is constrained not to move in the lateral direction. As the results, edges of the wound roll have a curved shape instead of a flat plane. (2) When the web is wound under the condition of unbalanced tension distribution in the width direction, the web shifts at first to the side where the web tension is larger, and then it returns like the case of the inclined core, if the web end is constrained. But if the web end can move freely in the lateral direction, most part of the web are correctly wound in spite of the unbalanced tension condition and the edges of the wound roll become flat except a few outer layers of the roll. These tendencies of the web shift may hold good for any web with different length. Both the web shift and the roll edge shape described in the above can be explained by knowing the web deformation during winding and the normal entry law of the web. (3) The telescoping suddenly occurs when an axial load acting on a wound roll increases gradually. The axial load where the telescoping occurs gets larger as a winding tension or a friction coefficient increases.
\end{abstract}

Key words : Simulation, FEM, Web handling, Winding, Roll defects, Friction, Lateral shift, Telescoping, Dishing

\section{1. 緒言}

フィルムや連続紙などいわゆるウェブと呼ばれる薄くて長い素材は，通常，製造や加工の最終工程でロール状 に巻き取られるが，巻き取り時またはその後の保管・輸送時に様々な欠陥（巻き取り欠陥）がロールに生じるこ とが知られている，巻き取り欠陥としては，層ずれ（湾弧，テレスコープなど），ゲージバンド，スターリング, 巻きしわ，コアの陷没・抜け，ブロッキング，段差痕などがある (向井，2005). これらを含めてウェブハンドリ ングで生じる様々なロールの久陥について，その特徵，発生原因，対策法などが，現場の経験をもとにまとめら れている (Smith, 2013). 巻き取り 欠陥はロールの内部応力の影響を強く受けること, 原因として軟巻き, 硬巻き, 巻き取り張力の不均一, ウェブ厚さの不均一などが挙げられてはいるが (向井, 2005), (Smith, 2013), 工学的な

No. 14-00430 [DOI: 10.1299/transjsme.2014dsm0335]

${ }^{* 1}$ 正員，フェロー，長岡技術科学大学名誉教授（テ940-2188 新潟県長岡市上富岡町 1603-1）

${ }^{* 2}$ 正員, 長岡技術科学大学 工学部 機械系

${ }^{* 3}$ 長岡技術科学大学 大学院

E-mail of corresponding author: yanabe@mech.nagaokaut.ac.jp 
レベルで欠陥の発生過程や発生メカニズムを取り扱った例は極めて少ない.

Lee ら (Lee, et al., 2009) は， ウェブの両端の張力差が， ウェブに曲げ変形を発生させ横方向変位（幅方向変位） を生じさせるとして，ローラで搬送されるウェブの横方向変位を計算する式を提案した．彼らは，実験用の巻き 取り機の近傍でウェブの横方向変位を測定し計算結果と比較しているが，巻き取ったロールの形状については言 及していない. 後藤・松原 (後藤, 松原, 2012) は, 巻き取ったロールに軸方向の振動加速度を与えた場合につ いて，ロールのウェブ各層に作用する慣性力とこれに対抗するウェブ層間の摩擦力の釣合から，ウェブ層のずれ

（テレスコープ）が発生する限界の加速度とずれが発生する層の半径位置を求める計算法を示した. 本報告は定 性的な議論としては納得的であるが，計算結果が一例だけで，ずれの大きさやどのようなずれ変形が生じるかに ついては述べていない.

筆者のうちのひとりは，これまで，平行でない 2 本のローラの間を走行するベルトの蛇行 (矢鍋他，2001) およ び傾いたローラを含む 4 本のローラ上を走行するフィルムの蛇行や折れしわ (矢鍋，猪股，2007)，フィルムの 2 次元巻取りとロールの内部応力分布 (Yanabe, et al., 2010) などに関して, 有限要素法汎用解析ソフトを用いたシミ ユレーションを行い, 蛇行の特徵, 折れしわの発生メカニズム, すべりやコア弾性がロールの内部応力分布に及 ぼす影響などを明らかにしてきた。

本研究では，ロールの巻き取り欠陥のうちウェブの幅方向のずれに着目して，これが発生すると思われる 3 ケ 一ス，傾いたコアでウェブを巻き取る場合，張力分布が不均一な状態でウェブを巻き取る場合，および層ずれの ないロールに軸方向荷重を加えた場合，についてこれまでの手法を用いてシミュレーションした．前 2 者につい ては，ウェブ後端の幅方向変位の拘束条件（拘束，自由）の影響についても検討している．本研究では，単純な モデルと任意なパラメータの值を用いているが，巻き取りにおけるウェブの横ずれやロールの層ずれの発生はウ エブの拘束条件と変形がわかれば説明できるなど有用な知見が得られたので，以下に報告する.

\section{2. シミュレーションモデルとシミュレーション方法}

本研究で取り扱った 3 ケース（Case A, B,C) を図1(a),(b), (c)に示寸. Case A はコアをウェブに対して傾けた状 態での巻き取り, Case B はウェブの張力が幅方向に不均一な状態での巻き取り, Case C は層ずれのないように巻 き取ったロールに軸方向荷重を加えた場合のウェブ層のずれ（テレスコープ）である．これらのシミュレーショ ンを FEM 汎用解析ソフト Marc 2012.1.0 で行った. 図 2 は用いた 3 次元巻き取りモデルで, ウェブの後端に張力 や変位の拘束条件を与えた. モデルは直径 $40 \mathrm{~mm}$, 長さ $60 \mathrm{~mm}$ の剛体円筒コアと長さ $L=3,3.32,5 \mathrm{~m}$, 幅 $w=20 \mathrm{~mm}$, 厚さ $t=0.5 \mathrm{~mm}$ のウェブからなっている. ウェブは, 長さ $1 \mathrm{~mm}$, 幅 $5 \mathrm{~mm}$, 厚さ $0.5 \mathrm{~mm} の 8$ 節点 6 面体のソリッ ド要素で分割した，座標軸は，初期位置におけるウェブの長手方向を $x$ 軸，厚さ方向を $y$ 軸，幅方向を $z$ 軸にと る. ウェブは等方性とし，ヤング率 $E=50,1000 \mathrm{MPa}$ ，ポアソン比 0.01 , 巻き取り張力 $T=25 \mathrm{~N} / \mathrm{m}$ （張力分布不均一 の場合は $3 \cdot 2 \cdot 1$ 参照) とした. 巻き取り時などにウェブの層間に作用する摩擦力 $F$ は, 摩擦係数 $\mu$, 押し付け 力 $P$, 寸べり速度 $V_{r}$, 基準すべり速度 $C$ を用いて, 式(1)で表されるとした。 この場合の摩擦力特性の概略を図 3 に示す．なお，この摩擦力特性の式はここで用いた FEM 汎用解析ソフトに標準装備されている.

$$
F=\mu P \frac{2}{\pi} \tan ^{-1} \frac{V_{r}}{C}
$$

本シミュレーションでは, 摩擦係数は, ウェブ層間で $\mu=1$, コアとウェブ間で $\mu=\infty$ とている $(C=0.1 \mathrm{~mm} / \mathrm{s})$ が,

3.1.1では, ウェブ層間で $\mu=\infty$ とした.

それぞれの場合のシミュレーション手順を以下に示す.

[Case A] 傾けたコアでウェブを巻き取る場合

(1)図 2 に示す剛体円筒のコアとソリッド要素で分割した長さ $3 \mathrm{~m}$ のウェブを作成し, ウェブの先端下側の節点を コアに固着させる. (2)ウェブ後端の 10 個の節点に同じ荷重 $t s n(=0.05 \mathrm{~N})$ を $-x$ 方向へ加えウェブに張力（ $T=t s n \times$ $10 / 0.02=25 \mathrm{~N} / \mathrm{m}$ ) を与える (荷重は 50 ステップで tsn の值になるように設定). (3)コア軸を $y$ 軸回りに+ $\beta^{\circ}\left(=+0.5^{\circ}\right.$ )

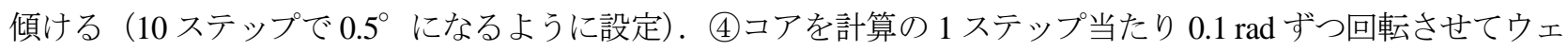
ブを巻き取る. この際, ウェブ後端の幅方向の変位を拘束した場合（後端拘束, $z_{e}=0$ ) と幅方向の変位を自由に した場合 (後端自由, $z_{e} \neq 0$ と標記) についてシミュレーションを行った. 計算結果からウェブの巻き取り過程 (ウ 
エブの横ずれと巻き取ったロールの側面形状）を明らかにする. 各計算ステップでは, ウェブの節点変位, 応力, すべり量，摩擦力，その他の諸量が静的釣り合い条件を満足するように収束計算される．ここでは，各ステップ の計算結果をつなぎあわせて巻き取り過程のシミュレーションとした.

[Case B] ウェブの張力分布が幅方向に不均一な状態で巻き取る場合

[Case A]の (1), (2), (4)を行う. (2)を行う際，ウェブの張力分布が不均一になるようにウェブ後端の節点に荷重 $t s n$ を加える（荷重分布の詳細は図 13 参照, 50 ステップ). (4)では, [Case A] と同様, ウェブ後端に幅方向変位の拘 束を与え, 後端は巻き取りが進むとコアに近づくとして, シミュレーションを行った.

[Case C] 層ずれのないロールに軸方向荷重を加えた場合のウェブ層のずれ

長さ $3.32 \mathrm{~m}$ のウェブを作成し[Case A]の (1)，(2)，(4)を行い，まずロールを層ずれのないように巻き取る. ウェブ の張力は $T=400 \mathrm{~N} / \mathrm{m}$, ヤング率は $E=1 \mathrm{GPa}$ とし，コアは傾けない. コアとウェブ間およびウェブ後端から $320 \mathrm{~mm}$ の区間のウェブ同士は固着 $(\mu=\infty)$, その他のウェブの区間ではスリップ $(\mu=1)$ とし, スリップ条件で巻き取った ウェブの長さが, Case A, B と同じになるようにした. 次に(5)を行う. (5)コアを固定し, 加速度による慣性力を口 ールの $+\mathrm{z}$ 方向へ加える. ウェブの密度は $\rho=10^{-6} \mathrm{~kg} / \mathrm{mm}^{3}$, 加速度の増加割合は 10 秒間 $(50$ ステップ) で $1 \mathrm{~g}(\mathrm{~g}=9800$ $\left.\mathrm{mm} / \mathrm{s}^{2}\right)$ とした. シミュレーション結果から, 加速度の増加に伴いウェブ層のずれ（テレスコープ）がどのよう に生じるかを観察した.

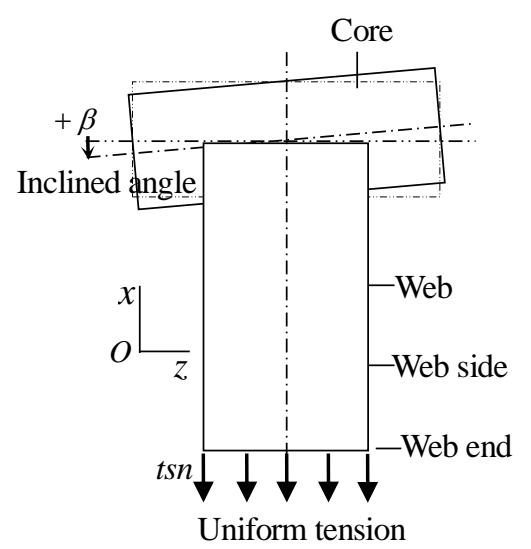

(a) Case A(Core inclination)

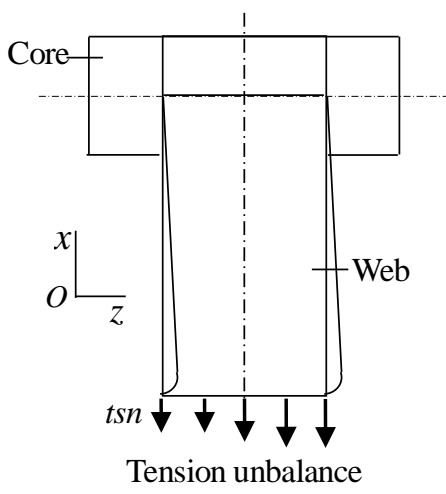

(b) Case B (Tension unbalance)

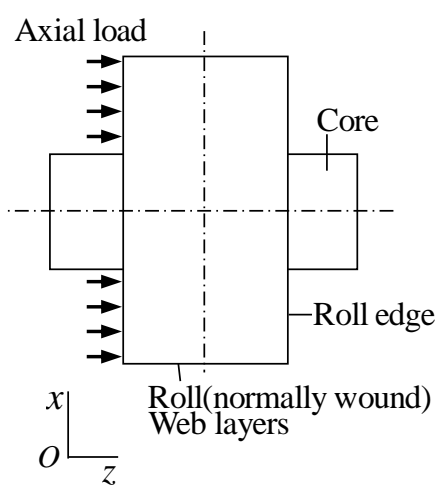

(c) Case C (Axial load)

Fig.1 Simulated three cases of web winding and external force conditions

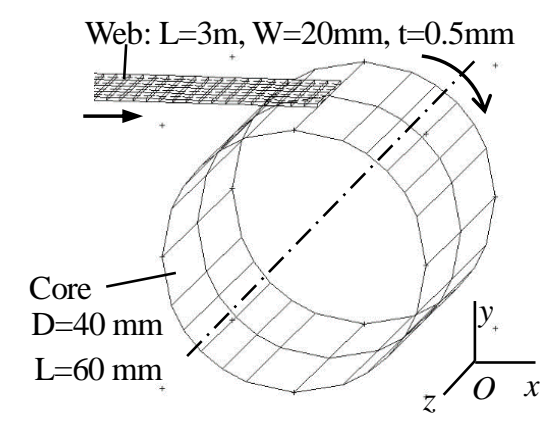

Fig.2 Three dimensional FEM winding model

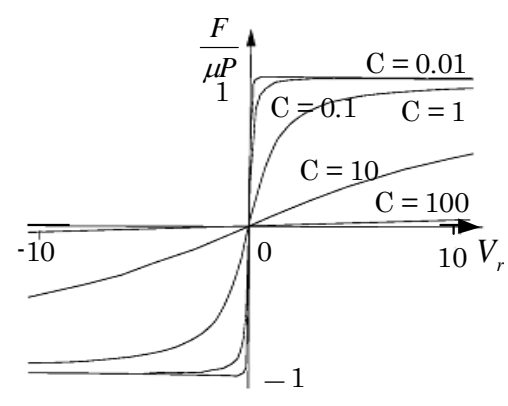

Fig.3 Friction force characteristics

\section{3. 巻き取りシミュレーションの結果と考察}

\section{$3 \cdot 1$ コアを傾けた場合の巻き取り過程（ウェブの横ずれとロールの側面形状）}

\section{$3 \cdot 1 \cdot 1$ コアを傾けた場合でウェブ層間にすべりがないとき}

図 2 の巻き取りモデルにおいて $L=5 \mathrm{~m}, T=25 \mathrm{~N} / \mathrm{m}, E=50 \mathrm{MPa}, \beta=0.5^{\circ}, \mu=\infty$ (層間すべりなし) として，ウェブ の巻き取り過程をシミュレーションした。 このときウェブ後端は幅方向へ変位しないように拘束されている $\left(z_{e}=0\right)$. 計算された巻き取り過程を図 4(a) (e)に示す. また, 図 4(b),(c),(d)を $y$ 軸上方から見たものを図 5(a),(b),(c) 
に示寸. 図中の\#200, \#500,\#1000 は計算の 200, 500, 1000 ステップ目を表している. 図 4(a)は巻き取り初期, 図 4(b),(c),(d)は, ウェブが $-z$ 方向, $+z$ 方向, $-z$ 方向へそれぞれ横ずれしながら巻き取られている状態を示す. 図 4(e) は巻き終わりの状態で，巻き取られたロールの側面に大きな凹凸が生じている. 図4(e)において，コアの中心を 通り $x$ 軸に垂直なロールの断面（上半分）を図 6 に示寸. 図より，ウェブの各層が左右に蛇行しながら巻き取ら れていることがわかる。この断面の側端のうねりが，図 4(e)のロール側面の凹凸に対応している．これを蛇行と 呼ぶ．なお，コアを傾けずにウェブを巻き取った場合，そのロールの側面は平らで凹凸は生じない。

図 5 において，巻き取り中にウェブがロールに最初に接触し始める位置を。印（点 $\mathrm{P}$ ）で表し，これを巻き取り 接触点と呼ぶことにする. 点 $\mathrm{P}$ の $z$ 座標を計算の 50 ステップおきに読み取った結果を図 7 に示す. 図 7 と図 6 とでは $z$ 軸方向が $90^{\circ}$ 異なっているが，両図の $z$ 方向変位の変化はよくあっている. 以上より, 長さ $5 \mathrm{~m}$ のウェ ブを $0.5^{\circ}$ 傾けたコアで巻き取ると，全長が巻き取られる間にウェブは 2 往復蛇行する. 巻き取られたロールは 側面に 2 個の凹凸を生じ，そのずれ量は約 $13.5 \mathrm{~mm}$ に達することがわかる.

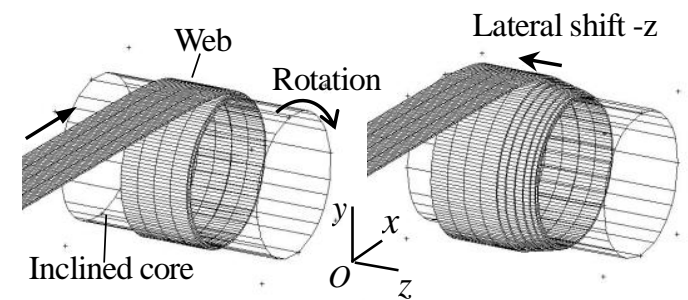

(a) \#200 (2.2 rotations)

(b) \#500 (7.0 rotations)

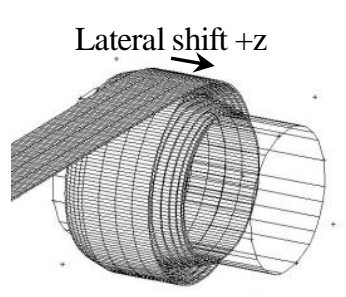

(c) \#1000 (15rotations)

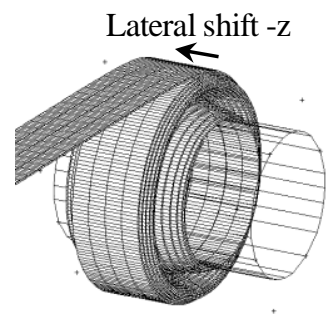

(d) \#1500 (23 rotations)

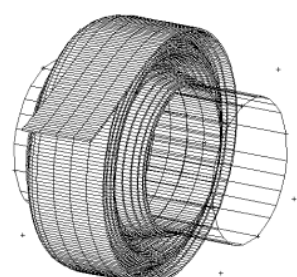

(e) \#1880 (29 rotations)

Fig. 4 A series of figures shows a winding process of a web for the case of the inclined core. The z-displacement of the web end is constrained not to move and the slip between web layers does not occur. The web is wound around the inclined core shifting laterally in $-\mathrm{z}$ and $+\mathrm{z}$ directions. As the result, the edge of the wound roll shows a two-cyclic curved pattern as shown in Fig. (e). $\beta=0.5^{\circ}, \mu=\infty, z_{e}=0, T=25 \mathrm{~N} / \mathrm{m}, E=50 \mathrm{MPa}$, and $L=5 \mathrm{~m}$.

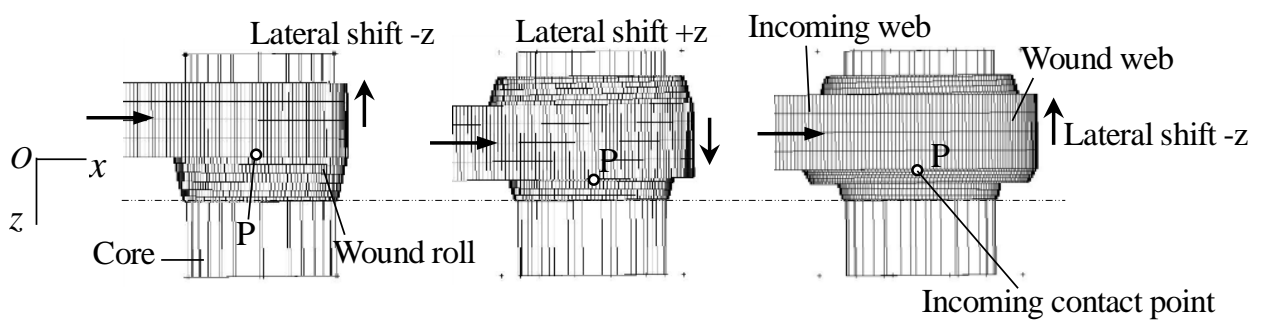

(a) \#500

(b) \#1000

(c) \#1500

Fig. 5 These figures are corresponding to Figs. 4(b), (c), and (d) viewed from +y direction. They show the lateral shifts of the wound web together with an incoming contact point $\mathrm{P}(\circ)$ which denotes the boundary of a wound web and an incoming web.

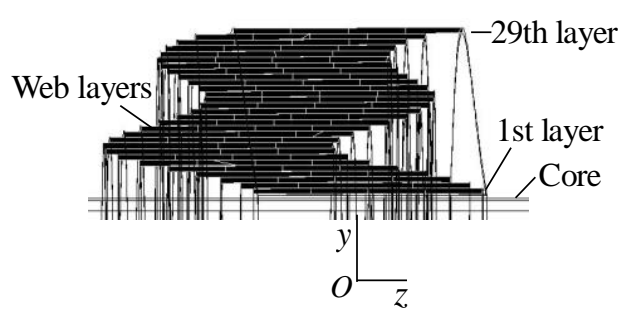

Fig. 6 The cross-section of the wound roll, which indicates a shape of the wound roll edge, shows a two-cyclic curved pattern. (Web width: $20 \mathrm{~mm}$, \#1880)

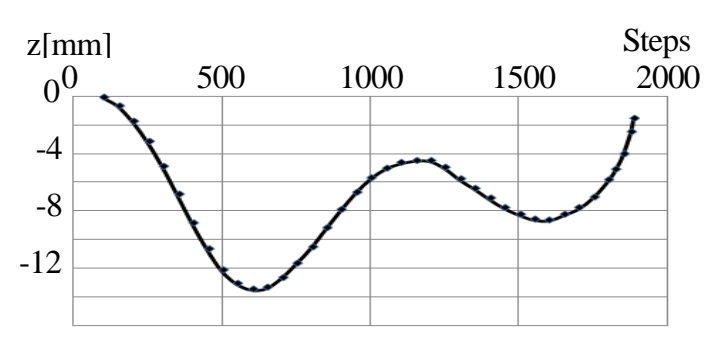

Fig. 7 The figure shows the variation of $\mathrm{z}$-displacement of the incoming contact point $\mathrm{P}$. It is associated with the shape of the roll edge surface (Fig. 6). 


\section{$3 \cdot 1 \cdot 2$ コアを傾けた場合でウェブ層間にすべりがあるとき}

実際に巻かれたウェブの層間にはすべりが存在する，そこで， $3 \cdot 1 \cdot 1$ のシミュレーションの条件（コア傾き 角 $\beta=0.5^{\circ}$, ウェブ後端の横方向変位を拘束 $\left.z_{e}=0\right)$ で摩擦係数 $\mu$ をから $\mu=1$ に, また, 計算時間の都合でウェ ブ全長を $5 \mathrm{~m}$ から $3 \mathrm{~m}$ に変更して巻き取りシミュレーションを行った. 巻き終わったロールの全体形状およびそ の断面を図 8(a),(b)にそれぞれ示す．また，図 8(c)には，各計算ステップにおける巻き取り接触点 $\mathrm{P}$ の（横）方 向変位を示す (図 7 に対応)。これらの図より，コアが傾きウェブ間にすべりがある場合，ウェブ後端の横方向変 位が拘束されていると，巻き取られたロールの側面は-z方向へゆるやかに湾曲寸ることがわかる（湾弧と呼ぶ）。 湾曲の方向は，コアを傾けたときウェブが緩む側に凸になっている．この特徴はウェブの長さが $5 \mathrm{~m}$ および $2 \mathrm{~m}$ の場合の計算でも観察された，以下に，コアの傾きにより湾弧が生じる理由について考察する.

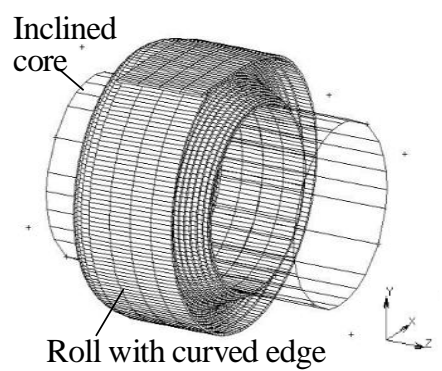

(a) Overall view of the wound roll

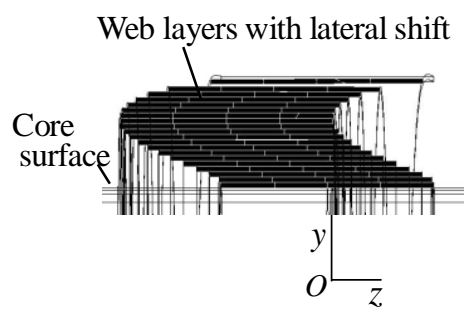

(b) Cross section of the roll (Shape of roll edge)

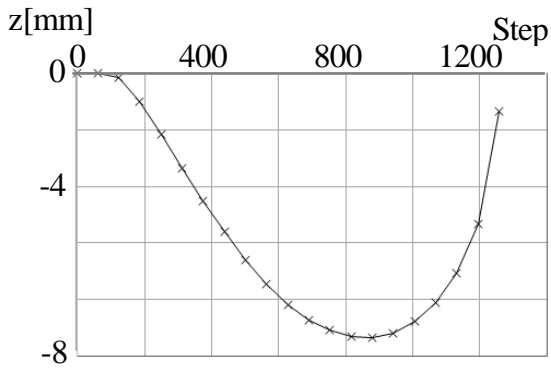

(c) Change of z-displacement of incoming contact point

Fig. 8 These figures show configuration characteristics of the roll which is wound around the inclined core. The slip between web layers is considered and the z-displacement of the web end is constrained. The edge of the wound roll shows a smooth curved pattern with one cycle. $\beta=0.5^{\circ}, \mu=1, z_{e}=0, T=25 \mathrm{~N} / \mathrm{m}, E=50 \mathrm{MPa}$, and $L=3 \mathrm{~m}$.

一般に，回転しているローラに進入するウェブはローラの軸に向かって垂直に進む性質（normal entry law）が ある (Pfeiffer, 1977). この性質を傾いたコアでウェブを巻き取る場合に適用すると，コア（ロール）とウェブの 角度的な関係が, 図9(a), (b)に示したような場合, 巻き取られるウェブ上の任意の点 $\mathrm{S}$ は, 矢印で示したように, 回転するコア (ロール) の軸に向かって垂直に進む. そのため, コアの回転により, ウェブは図(a)では右方向 $(+z)$ へ, 図(b)では左方向 $(-z)$ 一横ずれしながら巻き取られる. 図中, コア軸 $l$ に垂直な直線 $n$ と進入するウェブの なす角 $( \pm \varepsilon)$ をコアに対するウェブの進入角と呼び，これを直線 $n$ から矢印の向きに測るとすると，図(a)の進入 角 $+\varepsilon$ は正 $(y$ 軸まわりの回転角が正), 図(b)の進入角 $\varepsilon$ は負になる $(\varepsilon>0)$ 。この定義によれば, ウェブは進入

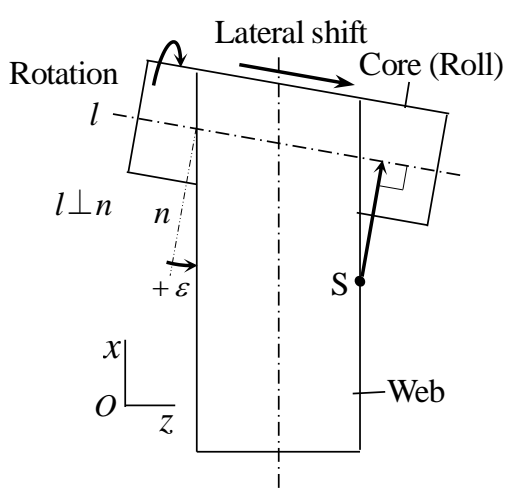

(a) Positive incident angle

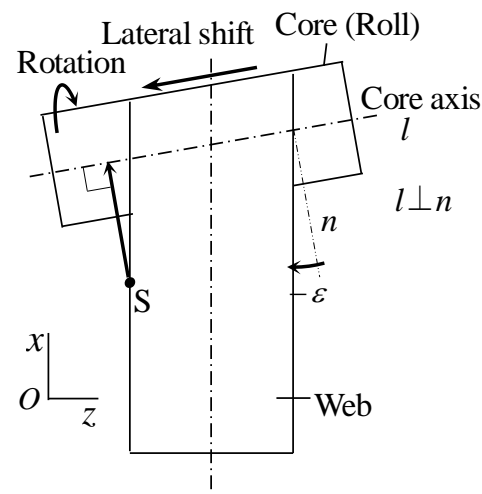

(b) Negative incident angle

Fig. 9 These two figures show the relationship between an incident angle $\pm \varepsilon$ and the lateral shift direction of the wound web. The incident angle is defined as an angle which is measured from the line $n$ normal to the core axis $l$ toward the incoming web side line as shown by a curved arrow. The angle is positive when it directs to the positive direction of $\mathrm{y}$-axis. Then, the web shifts to $+\mathrm{z}$ direction when the incident angle $(+\varepsilon)$ is positive, while it shifts to $-\mathrm{z}$ direction for the negative incident angle $(-\varepsilon)$ following the normal entry law. 
角を示す矢印の方向へ横ずれするので，ウェブは進入角が正であれば+ $z$ 方向へ，負であれば- $z$ 方向へ横ずれする といえる. このとき, 進入角の絶対值 $\varepsilon$ が大きいほど, 横ずれの速度は速くなる. こうしたウェブの横ずれ挙動 は，コアが水平になるように図 9(a), (b)全体を傾けた場合についても成り立つ. 以上のことから, 巻き取り中のウ ェブの横ずれを予測するには，コア（ロール）に対するウェブの進入角の正負を知る必要のあることがわかる.

ここではまず, 図 8 のシミュレーション結果について, その巻き取り過程を調べた. 結果を図 10(a) (d)に示す. なお，図 10 は, 図 9(a),(b)でウェブの後方下側からコア方向を見た図になる.図 10 には, 傾けたコア, コアに巻 き取られたウェブの部分，巻き取られていないウェブの部分（黒い部分）およびウェブ後端の断面（細長い白の 長方形）が見える. なお， ウェブ後端の鉛直および横方向変位 $(y, z)$ は計算中 $y_{e}=10 \mathrm{~mm}, z_{e}=0 \mathrm{~mm}$ に拘束されて いる（ウェブの進行方向の変位 $x$ は拘束されていない). 図 10(a) \#60 は, ウェブに張力を加えたあと, コアを鉛 直 $(y)$ 軸まわりに $+0.5^{\circ}$ 傾けたときの状態で, コアの傾きによる曲げモーメントで, コアに近いウェブの部分で 曲げ変形が見られる．それ以外のウェブの側端はウェブ後端までほぼ斜めの直線になっている．\#61 からコアの 回転（ウェブの巻き取り）が始まり，ウェブの形状は徐々に変化する. 図(b) \#135（コア 1.19 回転）では，ウェ ブの曲げ変形は消滅し，巻き取られていないウェブ（黒い部分）の側端はほぼ直線で $x$ 軸方向を向いている。 し かし，コアは $y$ 軸まわりに+0.5 傾いているため，鉛直上方から図(b)のコアとウェブの角度的な関係を見ると， 図 9(b)のようになり, ウェブは負の進入角を示す，その結果，ウェブは左 $(-z)$ 方向に横ずれしながら巻き取ら れ，その典型的な状態が図(c) \#500 (コア 7 回転) に示されている. その後ウェブは左方向への横ずれを続け, \#900 少し手前で横ずれの方向を反転して右方向へずれだす (図(d)\#1100).

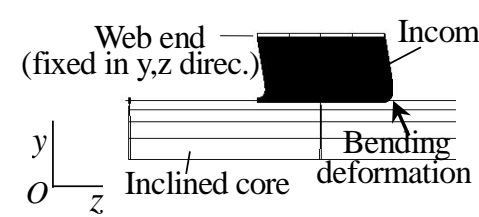

(a) \#60 inclining core

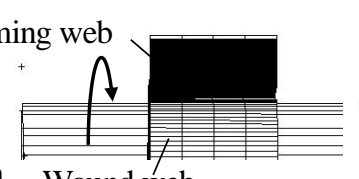

Wound web

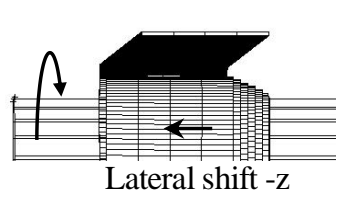

(c) \#500 (7.00 rotations)

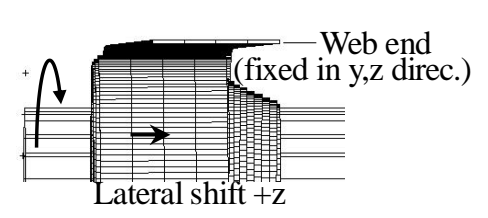

(d) \#1100 (16.6 rotations)

Fig. 10 A series of figures shows the winding process for the case of the inclined core viewed from $-x$ direction. The z-displacement of the web end is constrained not to move and the slip between web layers is considered. A bending deformation appears in the web near the inclined core (\#60). It soon disappears after the core rotates 1.19 rotations (\#135), and the side line of the incoming web becomes almost straight and the web incident angle becomes negative. Then the web is wound shifting to $-\mathrm{z}$ direction at first. But finally the web shifts to the $+\mathrm{z}$ direction. $\left(\beta=0.5^{\circ}, \mu=1, z_{e}=0\right.$, $T=25 \mathrm{~N} / \mathrm{m}, E=50 \mathrm{MPa}, L=3 \mathrm{~m}$ )

横ずれの反転理由を知るため, 図 10 の巻き取り過程について, $+y$ 軸方向から見たウェブ側端の $z$ 方向変形形 状 (ウェブ側端形状) がどのように変化するかをまず調べ, 次に, ウェブ側端の傾き角とコアの傾き角の関係（両 者の差が進入角になる）を調べた.

ウェブ側端形状の変化を図 11 に示寸. 図の縦軸は, 初期状態においてウェブ先端から測ったウェブの長さ方向 の位置 $X(=-x)$, 横軸はウェブ側端の $z$ 方向変位である. 実際の巻き取りでは, コア位置は変わらず, ウェブが コアへ近づくが，ここではウェブの側端形状の変化を比較するため, ウェブの位置は固定してある. 図中の\#60, \#135, \#300, ․は2, 計算の $60,135,300, \cdots$ ステップ目を, 曲線上の小さな。印 点 $\mathrm{P}(X, z)$ は巻き取り接触点 (図 5 参照) を, 点 T, E はウェブの先端, 後端を示す. 図 11 より, ウェブ側端の変形形状は以下のように変化することがわ かる. (1)初期状態および張力付加過程（\#50まで）では縦一直線だったウェブ唄端形状は，(2)コアを $y$ 軸まわり に $+0.5^{\circ}$ 傾け終えた時点 $(\# 60)$ で, コアに近い部分が $+z$ 方向に凸になるように曲げ変形する (図 10(a)に対応). その後, (3)\#135 ではウェブ側端形状はコア近傍を除き $x$ 軸方向を向く直線になる (図 10(b)に対応). (4)これ以降, 各計算ステップにおけるウェブ側端形状は, 巻き取られていないウェブの部分については点 $\mathrm{P}$ とェブ後端 $\mathrm{E}$ を 結ぶ線分 $\overline{P E}$ で表される. 図 11 より, \#135〜\#700 では計算ステップが進むにつれて, 点 $\mathrm{P}$ は- $z$ 方向へ移動（ウェ ブは-z方向へ横ずれ）するが，\#900〜\#1200 では逆に+z方向へ移動（横ずれ）する.

ここで, 線分 $\overline{P E}$ (巻き取られていなウェブの側端形状線）の縦軸（ $x$ 軸）からの傾き角を $\alpha$ とすれば，コアの 傾き角 $\beta$ を用いて, ウェブのコア（ロール）への進入角 $\pm \varepsilon$ は次式で表される.

$$
\pm \varepsilon=\alpha-\beta
$$


一方，図 11 より， $\alpha$ は巻き取り接触点 $\mathrm{P}$ の座標 $(X, z)$ より次式で計算される.

$$
\tan \alpha=|z| /(3000-X)
$$

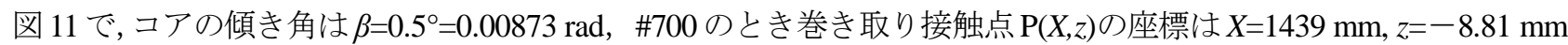

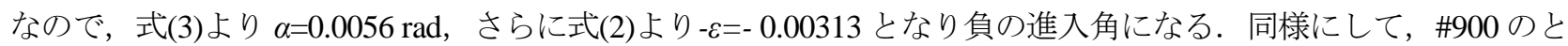
きは $X=1957 \mathrm{~mm}, z=-9.35 \mathrm{~mm}$ なので $\alpha=0.0090 \mathrm{rad},+\varepsilon=0.00027$ となり正の進入角になる. この結果, \#900 少し 手前で $\varepsilon=0(\alpha=\beta)$, 寸なわち, ウェブ側端形状を示す直線がコア軸に垂直になり, この時点でウェブの $-z$ 方向へ の横ずれが止まると思われる. しかしこのあとコアの回転が進むと, ウェブの横ずれは移動方向を反転して $+z$ 方 向へ向かう. 実際に, \#1000, 1100, 1200 における $\alpha$ の值は, $0.011,0.016,0.025 \mathrm{rad}$ と増加している. これは, 巻き 取り $(X$ の増加 $)$ が進むと式(3)の分母が小さくなり, $\alpha$ の值が増加し続け $\beta$ より大きくなるため, 進入角 $( \pm \varepsilon=\alpha-\beta)$ が正になる結果であると考えられる。

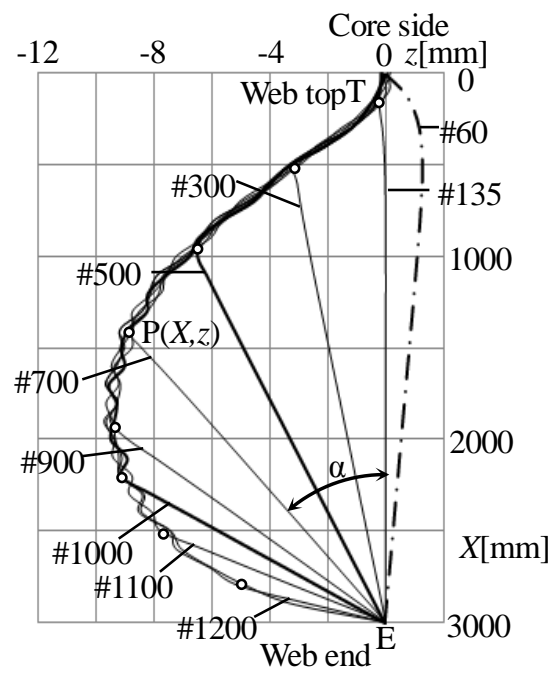

Fig. 11 Curves in this figure show lateral deformation shapes of the web side line at several calculation steps expanded on the $X$ -z plane. A mark $\circ$ on each curve denotes the incoming contact point $(\mathrm{P})$ which is the boundary of the wound web (TP) and the incoming web $(\overline{P E}) . \alpha$ is an angle between $X$-axis and $\overline{P E}$, and $\alpha$ gradually increases from 0 . When $\alpha<\beta(\beta$ : the core inclined angle), the incident angle of the incoming web to the core becomes negative, and the web shifts to $-\mathrm{Z}$ direction. When $\alpha>\beta$, the incident angle becomes positive, and the web shifts to $+\mathrm{z}$ direction. Then $\alpha=\beta$ is the transition point of the web lateral shifting. $\beta=0.5^{\circ}, \mu=1, z_{e}=0, T=25 \mathrm{~N} / \mathrm{m}, E=50 \mathrm{MPa}$, and $L=3 \mathrm{~m}$.

\section{$3 \cdot 1 \cdot 3$ コアを傾けた場合のウェブの横ずれとロールの湾弧の発生メカニズム}

3・1 2 のシミュレーション結果をもとに, ウェブ層間の摩擦力を考慮し, 均一な張力分布のもと, コアを傾 けてウェブを巻き取った場合のウェブの横ずれとロールの湾弧の発生メカニズムを模式的に示したのが図 12(a) (f)である．なお，ウェブ後端は幅方向に変位しないように常に拘束されている．図ではウェブの長さ方向を極端 に短く描いてある.これらの発生メカニズムは次のように考えられる. (1)図(a)は，水平に置いたコアに対してウ エブを垂直に配置し，その先端をコアに固着させ，後端に均等な張力を加えた状態を示す．(2)図(b)は，図(a)の状 態からコアを角度 $\beta(>0)$ 傾け, ウェブのコア近くに曲げ変形が生じた状態を示す. (3)コアの傾きによるウェブの曲 げ変形は，コアが回転し始めてしばらくすると消滅し，図(c)の状態になる.ここで，ウェブ全体は $z$ 軸に垂直に なり，傾いたコアに対して負の進入角 $(-\varepsilon=-\beta)$ を示す.このためコアの回転が進むと，ウェブは左方 $(-z$ 方向 $)$ 几横 ずれしながら巻き取られる. (4)図(c)以後に巻き取られるウェブは, $x$ 軸から左に角度 $\alpha$ 傾いて図(d)のようになり, コアに対して負の進入角を示す. 進入角の大きさ $\varepsilon(=\beta-\alpha)$ は次第に小さくなるので, ウェブの左方への横ずれの速 度も小さくなる. (5) $\varepsilon$ がゼロ $(\beta=\alpha)$ になるとウェブがコアに垂直に進入するようになり， ウェブの横ずれは停止す る (図(e)).しかし，(6)さらに巻き取りが進むと， $z$ 方向変位を拘束されているウェブ後端はこのまま上方 $(x$ 軸方 向)へ移動し，これにともないウェブ側端の傾き $\alpha$ が更に増加寸る．その結果，ウェブの進入角は正 $(+\varepsilon=\alpha-\beta>0)$ 
になり，ウェブは反転して右方向へ横ずれし始める（横ずれの反転）。横ずれの速度は急に速くなり，ウェブ後端 がロール上に乗り上げて計算が止まる．以上の結果，巻き取られたロールの側面には，コアの傾きでウェブが緩 み側になる方（左側）に凸の緩やかな湾曲（湾弧）が 1 個生じることになる．この湾曲はコアに近い側で緩やか でロール外周近くで急になる，この巻き取り過程はウェブの長さに関係なく成り立ち，長いウェブでも，短いウ ェブでも, 湾曲が 1 個だけ生じることになる. なお， $3 \cdot 1 \cdot 1$ で説明したウェブ間固着 $(\mu=\infty)$ の場合，同じコ アの傾きでも巻き取られたロールの側面には 2 往復の蛇行が生じている. これは $\mu=\infty の$ 場合, $\mu=1$ の場合に比べ て，巻き取り接触点 $\mathrm{P}$ （。印）前後におけるウェブの傾き角の変化が大きいためと思われる.

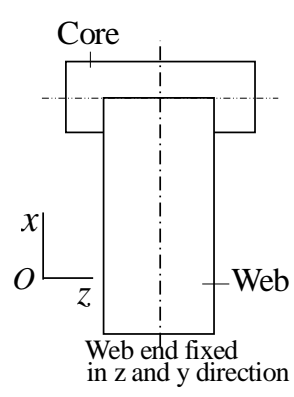

(a) Applying a uniform tension

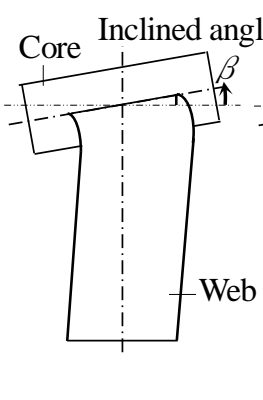

(b)Inclining core
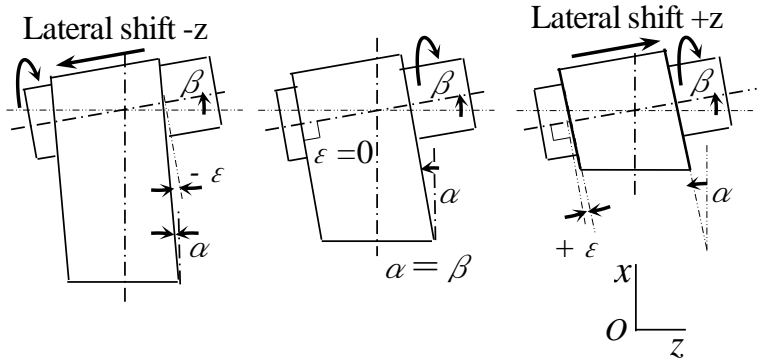

(f)End of winding

d)Negative incident (e)Transition of lateral shift (Positive incident angle)

Fig. 12 A series of figures schematically illustrates a development of the lateral shift of the web and the roll edge when the web is wound around the inclined core. The web end is constrained not to move laterally and the slip between the web layers is assumed. In this case, only one smooth curved pattern is observed on the edges of the roll. The curved pattern bends to the side where the web becomes loose due to the core inclination.

\section{$3 \cdot 2$ ウェブの張力分布が不均一な場合の巻き取り過程（ウェブの横ずれとロールの側面形状） \\ $3 \cdot 2 \cdot 1$ ウェブの不均一な張力分布}

ウェブの幅方向張力分布の不均一は，しばしば，ロールの層ずれの原因として挙げられる．実機における巻き 取り張力分布の不均一は様々な形があると思われるが，ここでは図 13 に示すように， ウェブ後端の 10 個の節点

(図では 2 個ずつ重なっている) に下向き矢印」で示寸大きさの異なる引張り荷重 $t s n$ を与えて張力分布の不均 一とした．これによる複数のウェブ位置 $X$ （図 11 の $X$ と同じ）における引張り応力 $\left(\sigma_{11}\right)$ の幅方向分布を折れ 線または直線で同図に示した. 図より, 引張り応力の幅方向分布は, ウェブ後端 $X=3000 \mathrm{~mm}$ では大きく変動して いるが， ウェブ後端部の $X=2500,2800 \mathrm{~mm}$ ではほぼ直線になりウェブ右側が左側より応力值が大きいこと, $X=0$ 〜 $1500 \mathrm{~mm}$ では幅方向にほとんど均一な応力分布になっていることがわかる.この引っ張り応力分布により曲げ

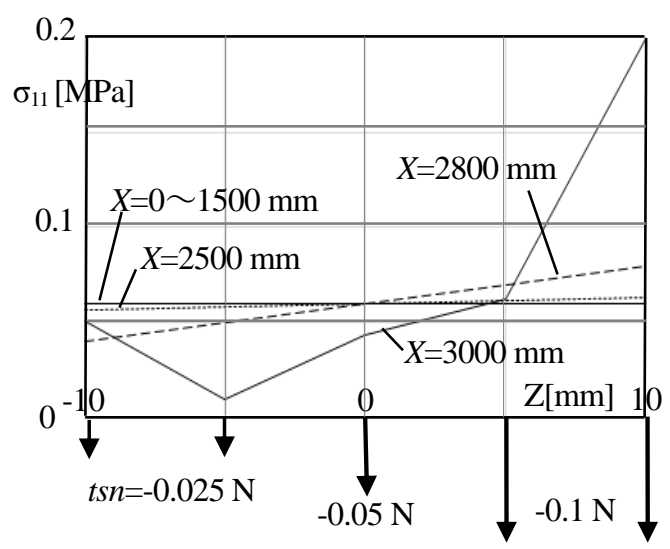

Fig. 13 This shows both the unbalanced tension and the tensile stress distributions across the web width. The tensile stress of the web right side is larger than that of the left one in the end part of the web (X=2500, $2800 \mathrm{~mm})$, while they are almost the same for $\mathrm{X}=0 \sim 1500 \mathrm{~mm}$. 
モーメントが形成され，後に示すように，ウェブの後端部で面内の曲げ変形が生じ，それ以外の部分ではほとん ど曲げ変形が生じない（ウェブ側端が直線になる）ことになる（図 15(a), (b)参照）。

\section{$3 \cdot 2 \cdot 2$ 張力分布が不均一な場合の巻き取り結果と考察}

コアを傾けず $(\beta=0)$, ウェブ層間の摩擦力を考慮して $(\mu=1)$, 上記の不均一な張力分布で巻き取りシミュレー ションを行った (図 1(b)参照). なお, ウェブ後端の $z$ 方向変位は拘束されている $\left(z_{e}=0\right)$. 以下に結果を示す. 図 14(a) は $3 \mathrm{~m}$ のウェブを巻き取ったロールの全体図（20 層)，図(b)はそのロールのコア軸を含む断面，図(c)は 各計算ステップにおける巻き取り接触点の $z$ 方向変位を示す. これらの図より, 巻き取られたロールの側面は, ウェブ張力が大きい側（+ $z$ 方向）に凸の状態で緩やかに湾曲していることがわかる（湾弧）。沜横ずれ量 は，最大で約 $3.6 \mathrm{~mm}$ であった。

図 15(a) (e)に，この場合の巻き取り過程のシミュレーション結果を示す. 本図は先の図 10(a) (d) と同様な形で 描かれていて, 各図には, コア (傾きなし), コアに巻き取られたウェブの部分, 巻き取られていないウェブの部 分 (黒い部分) およびウェブ後端の断面（白の細長い長方形）が見える. 図 15(a) \#50 は，ウェブに不均一な張力 を加え終わった瞬間で，ウェブの後端部分に張力の大きい側（右側）を凸にした曲げ変形が見られる.この部分 以外では，ウェブの側端は傾いた直線でウェブ先端（コア）まで続く．本図を図 10(a)と比較すると，ウェブの面 内の曲げ変形は，コアを傾けた場合はコア付近に，張力不均一の場合は張力を加えているウェブ後端付近に生じ ていることがわかる. 図 15(a)では，コアは傾いておらずウェブはコアに対して正の進入角を持つ(図 9(a)参照). このためコアが回転し始めると（\#51～), ウェブは右 $(+z)$ 方向に横ずれしながら巻き取られる. この状態を図 (b) \#100 (コア約 0.8 回転) および図(c)\#500 に示す. その後, ウェブは\#1000 付近で横ずれの方向を反転し (図(d)),

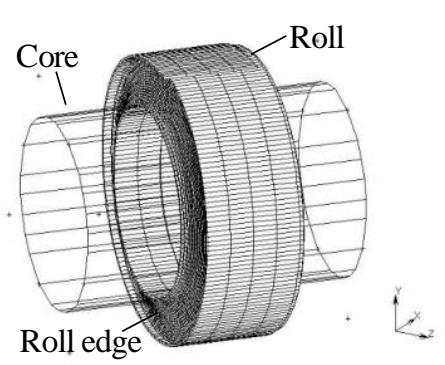

(a) Overall view of the wound roll

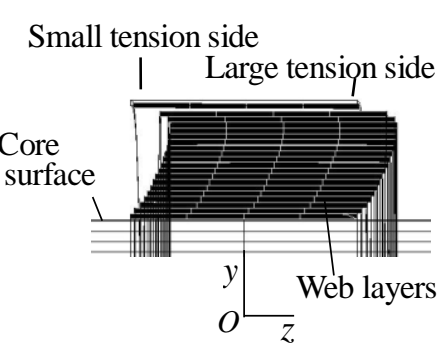

(b) Cross section of the roll (Shape of roll edges)

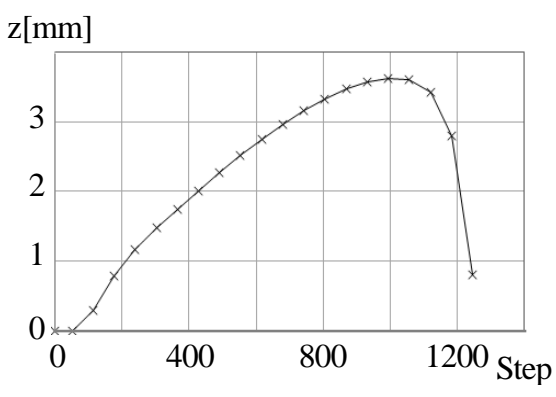

(c) Change of z-displacement of incoming contact point

Fig. 14 These figures show configuration characteristics of the roll which is wound under the unbalanced tension condition. The constraint of the web end and the slip between web layers are assumed. The edge of the wound roll shows a smooth curved pattern with a distorted one cycle. The curved pattern bends to the side where the web tension is larger. $\beta=0, \mu=1$, $z_{e}=0, T_{\text {ave }}=30 \mathrm{~N} / \mathrm{m}, E=50 \mathrm{MPa}, L=3 \mathrm{~m}$.

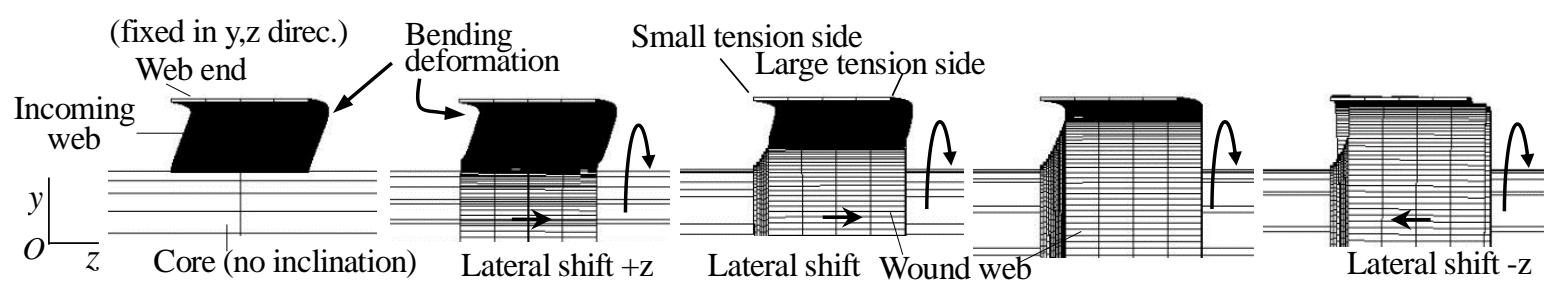

(a)\#50 end of tensioning (b) \#100 (0.8 rotations) (c) \#500 (7.2 rotations) (d) \#1000 (15 rotations) (e) \#1250 (19 rotations)

Fig. 15 A series of figures shows the web winding process viewed from $-\mathrm{x}$ direction for the tension unbalance case. The core is not inclined, the z-displacement of the web end is constrained not to move and the slip between web layers is considered. Figure (a) shows the end state of applying the unbalanced tension to the web and the bending deformation due to the unbalanced tension is observed near the web end. This bending deformation remains during the winding. The web shifts to $+\mathrm{z}$ direction (the larger tension side) at first (Figs. (b) and (c)) and then it shifts to the opposite direction near the end of winding (Fig. (e)). The change of the web shift direction is originated from the bending deformation of the web. $\beta=0$, $\mu=1, z_{e}=0, T_{\text {ave }}=30 \mathrm{~N} / \mathrm{m}, E=50 \mathrm{MPa}, L=3 \mathrm{~m}$. 
今度は左方向へ横ずれしながら巻き取られる（図(e)\#1250).

図 16 に, この場合 (張力分布が不均一) のウェブの側端形状の変化を示す. 縦軸, 横軸および記号の意味は図 11 の場合（コアを傾けた場合）と同じである. 図中の。印（点 P) は巻き取り接触点を示す. 図の\#1, \#50 はウェ ブ後端に図 13 に示した不均一な張力分布を加え始めた瞬間および加え終わった瞬間で, この不均一な張力分布に よってウェブがその後端部分 $(2000<X<3000)$ で曲げ変形していることがわかる.この曲げ変形はその後のウェ ブ側端形状でも常に認められる. \#100, \#300, \#500, \#800では，。印よりすぐ下側のこれから巻き取られるウェブ側 端形状は左斜め上方に向く曲線になっている．このときウェブとコア（ロール）の角度的な関係は図 9(a)をコア が水平になるように傾けた図のようになり，正の進入角となる．従って，ウェブは $+z$ 方向へ横ずれする（。印が 右方向へずれていく)ことになる. \#1000では，。印よりすぐ下側のウェブ側端形状はほぼ垂直上方を向いている が，これに続くウェブ側端形状はほぼ斜め右上に向かう（ウェブのコアへの進入角が負）。このため, \#1000 付近 でウェブの右方向への横ずれは終わり，その後，横ずれは反転して左方向へ進む．\#1200では左方への横ずれが 継続している.

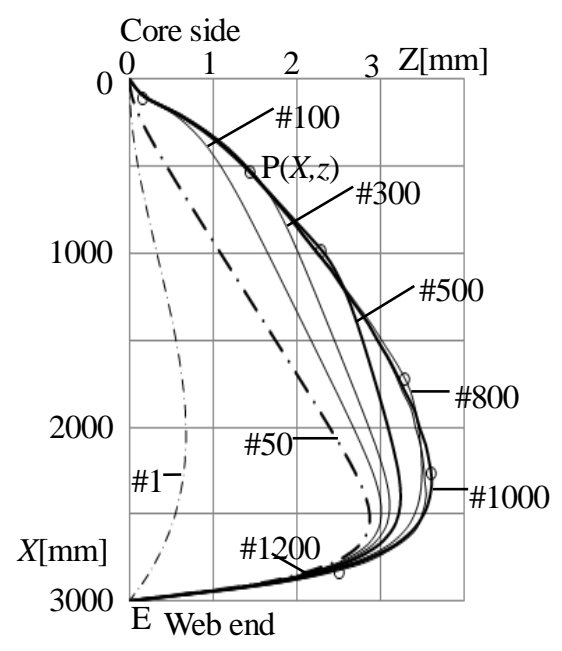

Fig. 16 Curves in this figure show the lateral deformation shapes of the web side line at several calculation steps expanded on the $X$-z plane. The mark $\circ$ on each curve denotes the incoming contact point $(\mathrm{P})$ which is the boundary of the wound web and the incoming web. In the beginning, the incoming web side line directs to the upper left against the core and this mean the positive incident angle of the web. Then the web shifts to $+\mathrm{z}$ direction (the larger tension side). Near the end of winding (\#1200), the incoming web side line directs to the upper right due to the web bending deformation. Then the incident angle becomes negative and this makes the web shift to $-\mathrm{z}$ direction (the smaller tension side). $\left(\beta=0, \mu=1, z_{e}=0\right.$, $\left.T_{\text {ave }}=30 \mathrm{~N} / \mathrm{m}, E=50 \mathrm{MPa}, L=3 \mathrm{~m}\right)$

\section{$3 \cdot 2 \cdot 3$ ウェブの張力分布不均一によるウェブの横ずれとロールの湾弧の発生メカニズム}

3·2 - 2 のシミュレーション結果をもとに, ウェブ層間の摩擦力を考慮し，コアを傾けずに，不均一な張力分 布のもとでウェブを巻き取った場合のウェブの横ずれとロールの湾弧の発生メカニズムを模式的に示したのが図 17(a) (e)である. ウェブ後端の幅 $(z)$ 方向変位は拘束されていて, 図は図 12 の場合と同様な形で描かれている. これらの発生メカニズムは次のように考えられる. (1)図(a)は初期状態を示寸. (2)図(b)は, 図(a)のウェブの後端に 不均一な張力分布を加えた状態で，これによりウェブの後端部に曲げ変形が生じる一方， ウェブ先端部の側端形 状は左上方を向く直線になる. (3)図(b)の状態でウェブのコアへの進入角は正 $(+\varepsilon>0)$ になるで，コアが回転し 始めると，ウェブは右方向 $(+z)$ 一横ずれしながら巻き取られる (図(c) $)$. この間，ウェブの横ずれの速度はほぼ一 定である. (4)巻き取りが更に進むと, 曲げ変形したウェブの部分が巻き取られるようになり，曲げ変形の極大点 付近でウェブはコアに垂直に進入するようになる（進入角ゼロ： $\varepsilon=0$, 図(d)). ここでウェブの右方向への横ず れは停止する.しかし，(5)図(d)の状態からさらにコアが回転すると，曲げ変形したウェブの極大点以降が巻き取

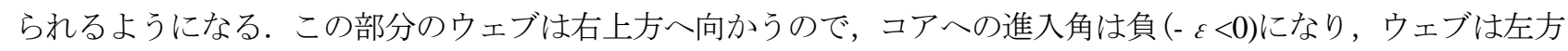
向 (-z)へ横ずれしだす (横ずれ方向の反転)。横ずれの速度は急に速くなり，ウェブ後端がロールに乗り上げて計 算が止まる．以上の結果，巻き取られたロールの側面には，ウェブの張力が大きい側（右側）を凸にした湾曲（湾 
弧）がひとつ生じることになる (図 14 参照)。こうしたウェブの横ずれ挙動は，ウェブ後端の幅 $(z)$ 方向変位の 拘束条件，ウェブの寸法やヤング率の影響を強く受けると考えられる.

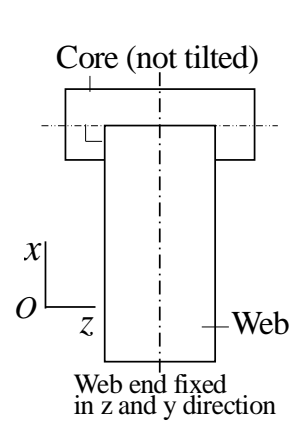

(a)Initial state

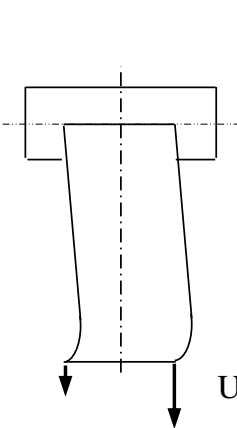

(b)Unbalanced tension applied
Lateral shift $+\mathrm{z}$

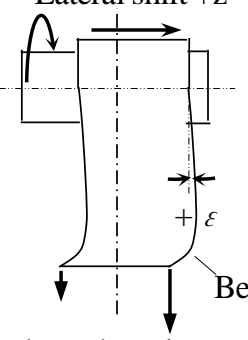

Unbalanced tension

(c)Rotation starts

(Positive incident angle)

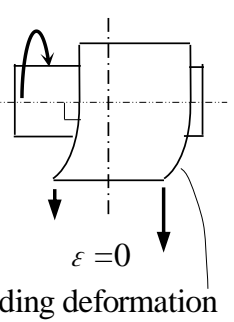

(d)Lateral shift transition point
Lateral shift $-\mathrm{z}$

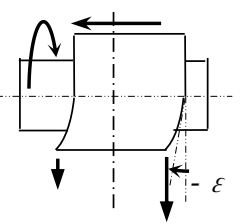

(e)End of winding

(Negative incident angle)

Fig. 17 A series of figures schematically illustrates a development of a lateral shift of a web and edges of a roll which is wound under an unbalanced tension condition. The web end is constrained not to move laterally and a slip between the web layers is considered. At first, the web shifts to the larger tension side $(+\mathrm{z})$, while the web shifts to the smaller tension side $(-\mathrm{z})$ near the end of winding. As a result, the edge of the roll shows a curved pattern with a distorted one cycle. The curve bends to the tension larger side.

\section{$3 \cdot 3$ ウェブ後端の幅方向変位を拘束しない場合の巻き取り過程}

これまでのシミュレーションでは，ウェブ後端の幅（z）方向の変位を常にゼロ $z_{e}=0$ となるように拘束してい た.ここでは，ウェブの後端が幅方向へ自由に動けると仮定（ $z_{e} \neq 0 ）$ して巻き取りシミュレーションを行い，ウ エブ後端の幅方向変位の拘束条件がロールの層ずれに及ぼす影響について調べた.

\section{$3 \cdot 3 \cdot 1$ コアを傾けた場合でウェブ後端の幅方向変位を拘束しないときの結果}

コアを傾けた $3 \cdot 1 \cdot 2$ の場合について， ウェブ後端の幅方向変位拘束を取り除いて（ウェブ後端自由で）巻き 取りシミュレーションを行った。図 18(a),(b)に 1000 ステップ時のロールの全体形状，ロール断面，図(c)に巻き 取り接触点の $z$ 方向変位の変化をそれぞれ示す. 図(c)には図 8(c)の結果（ウェブ後端の幅方向変位を拘束した場 合）も示してある.また，この場合の巻き取り過程を図 19(a) (g) に示す.図 19 の描き方は図 10 とほぼ同じで, 図中の。印は巻き取り接触点の位置を，垂直な一点鎖線は計算開始時のウェブの幅中心位置を示している. 図 19 (a), (b), (c) は，ウェブに規定の張力を加え終わった時点（\#50），コアを傾け終わった時点（\#60），およびコアが 1.03 回転した時（\#125）の結果である. その後，巻き取りが進むと，ウェブは左方向（-z）八横ずれし続けた（図 (d), (e), (f)）のち，突然，同じ方向 $(-z)$ へ大きなずれを生じる (図 $(\mathrm{g})$ )。計算中，ウェブ後端（細長い白の長方 形）は $z$ 方向の変位を拘束していないため- $z$ 方向へ移動し続ける.

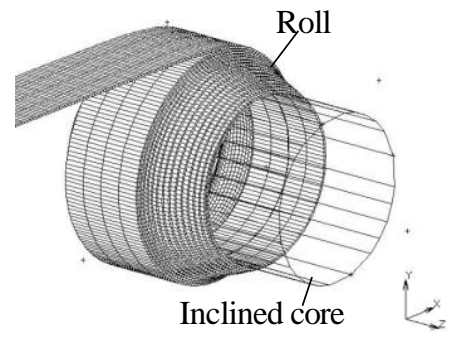

(a) Overall view of the wound roll for the case of inclined core

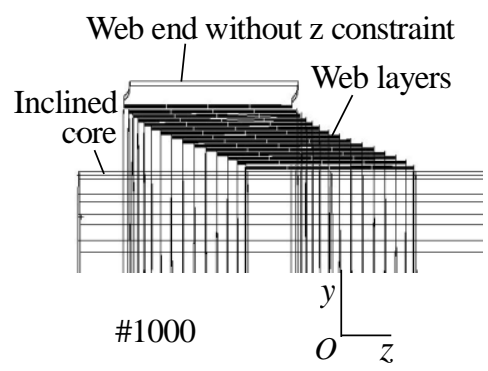

(b) Cross section of the roll

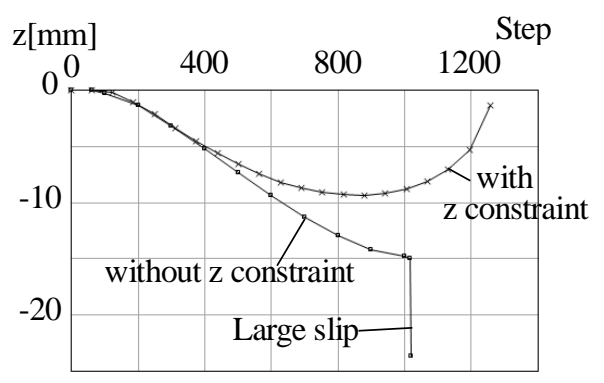

(c) Change of z-displacement of incoming contact point

Fig. 18 These figures show configuration characteristics of the roll which is wound around the inclined core without the constraint of the lateral (z) displacement of the web end. The web keeps shifting to the lateral side where the web becomes loose due to the core inclination. $\beta=0.5^{\circ}, \mu=1, z_{e} \neq 0, T=25 \mathrm{~N} / \mathrm{m}, E=50 \mathrm{MPa}$, and $L=3 \mathrm{~m}$. 


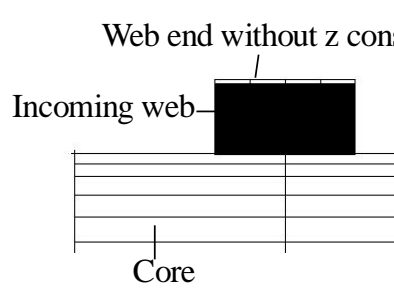

(a) \#50 tension applied

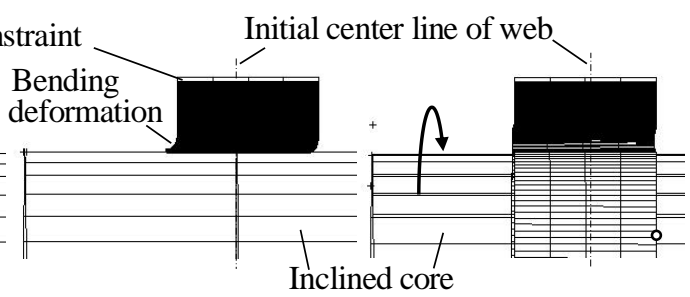

(b) \#60 Inclining core (c) \#125 (1.03 rotations)

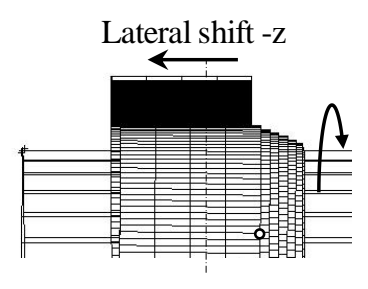

(d) \#500 (7.00 rotations)

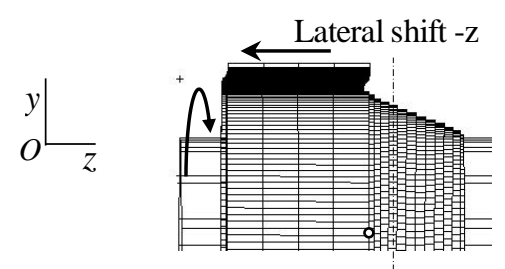

(e) \#900 (13.4 rotations)

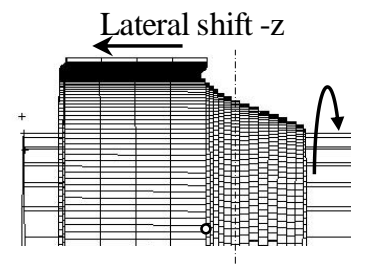

(f) \#1017 (15.2 rotations)

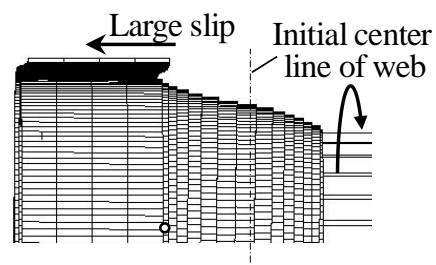

(g) \#1018 large slip

Fig. 19 A series of figures shows the winding process when the core is inclined and the lateral displacement (z) of the web end is not constrained. A bending deformation appears in the web close to the inclined core (Fig. (b)). It soon disappears after the core starts to rotate (Fig. (c)). In Fig. (c), the web incident angle is negative, and then the web shifts to the side (-z) where the web becomes loose due to the core inclination. The web continues shifting together with the unconstrained web end and finally a large slip occurs. $\left(\beta=0.5^{\circ}, \mu=1, z_{e} \neq 0, T=25 \mathrm{~N} / \mathrm{m}, E=50 \mathrm{MPa}, L=3 \mathrm{~m}\right)$

以上の結果から，コアを傾けてウェブを巻き取った場合，ウェブ後端が幅方向へ自由に動けると，ウェブは一 方向へ横ずれし続けながら巻き取られ，横ずれの反転は生じないと言える。こうした巻き取り状況は，ウェブ後 端の幅方向変位を拘束した場合と状況と大きく異なっている (図 10, 図 18(c)参照).

\section{3・3－2 ウェブの張力分布が不均一な場合でウェブ後端の幅方向変位を拘束しないときの結果}

ウェブ張力分布が不均一な $3 \cdot 2 \cdot 1$ の場合について, ウェブ後端の幅方向変位拘束を取り除いて（ウェブ後端 自由で）巻き取りシミュレーションを行った. 図 20(a), (b) に 1250 ステップ時のロールの全体形状とロール断面 を示す. 両図より, 張力分布に不均一があっても, ウェブ後端の幅方向変位拘束がない場合, 巻き取られたロー ルの側面は，外周部を除けば全く平坦であることがわかる．ロールの外周部は，張力不均一で曲げ変形したウェ ブ部分を巻き取っているため，ウェブは張力の弱い側へ少し横ずれする．こうしたウェブ後端自由の結果をウェ ブ後端拘束の結果 (図 14(a),(b)) と比較すると, ウェブ後端の拘束条件がいかに巻き取られたロールの側面形状 に大きく影響するかがよくわかる.

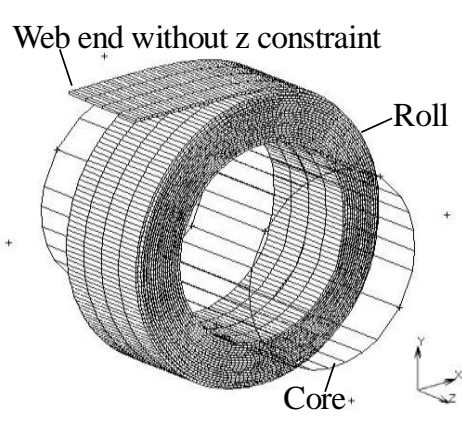

(a) Overall view of the roll wound under unbalanced tension condition

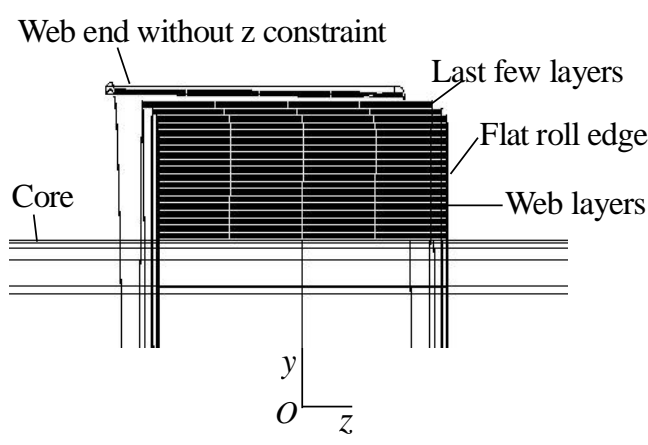

(b) Cross section of the wound roll (\#1250)

Fig. 20 These figures show configuration of the roll which is wound under the unbalanced tension condition without the constraint of the web end lateral displacement (z). The wound roll edge shows an almost flat surface except the last few web layers. This is an outstanding difference comparing with the smooth curved edge of the roll (Fig.14) which is wound constraining the lateral displacement (z) of the web end. $\beta=0, \mu=1, z_{e} \neq 0, T_{\text {ave }}=30 \mathrm{~N} / \mathrm{m}, E=50 \mathrm{MPa}, L=3 \mathrm{~m}$. 
図 21(a) (d) にこの場合の巻き取り過程を示す．図 21 の描き方は図 10, 15, 19 と同じである. 図 21 より以下の ことがわかる. 図 21(a) \#50 は, ウェブに不均一な張力分布を加え終わった状態を示している. ウェブ後端部に曲 げ変形を生じるが，ウェブ後端が- $z$ 方向に移動するのでウェブの先方部分はコアに対して垂直になる. このため, コアが回転しだすと, ウェブは横ずれを生じることなく巻き取られ，ロールの側面は平坦になる (図 (b), (c)). 巻き取りの終わりに近い図(d)\#1250では, 曲げ変形しているウェブ後端部を巻き取るため, ウェブは- $z$ 方向にわ ずかに横ずれする. もし， ウェブの長さが十分長く，かつ， ウェブの幅方向変位が拘束されていなければ， ウェ ブ張力の分布が不均一であっても, 巻き取られたロールの側面はほとんど平坦になると考えられる. 本論文では, 計算時間やパラメータ数の低減のため, 幅方向変位を拘束したウェブ後端のコア方向への移動を許したモデルを 用いているが，実際の巻き取りでは，上記のウェブ後端は移動しないことなどを考慮する必要がある.

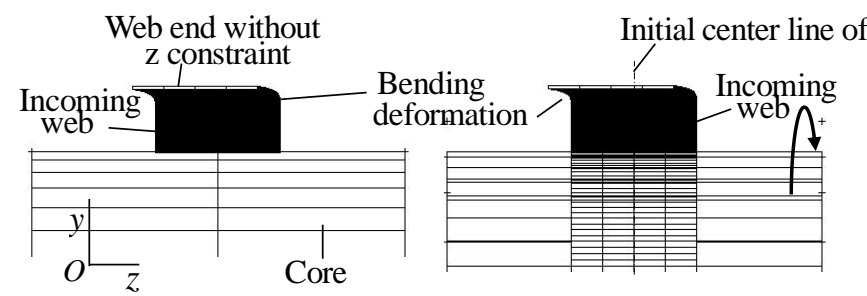

(a) \#50 unbalanced tension applied (b) \#100 (0.8 rotations)

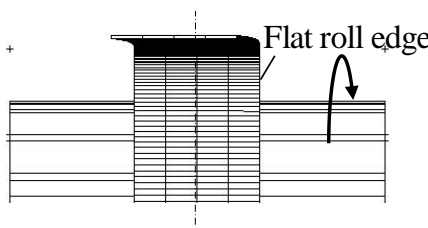

(c) \#1000 (15.1 rotations)

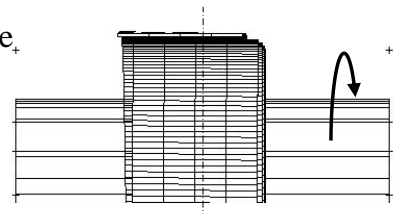

(d) \#1250 (19.1 rotations)

Fig. 21 These figures show the winding process for the case of the unbalanced tension. The lateral displacement (z) of the web end is not constrained. The incoming web side line is almost straight and perpendicular to the core, even though the bending deformation due to the unbalanced tension is always observed near the web end. Because of the incoming web direction, the roll is wound so that the roll edge is almost flat except the last few web layers.

\section{$3 \cdot 4$ 軸方向分布荷重によるロールウェブ層のずれ（テレスコープ）}

これまで巻き取り中に生じるウェブの横ずれとロールの層ずれについて述べた.ここでは，層ずれのないよう に巻き取ったあとのロールに軸方向分布荷重（加速度による慣性力）を加えて，ロールのウェブ層がどのように ずれるかをシミュレーションした ( 2 章 Case (C)参照). $T=400 \mathrm{~N} / \mathrm{m}, E=1 \mathrm{GPa}, \mu=1, \beta=0$ (均一張力, コア傾きなし) のときの結果から, 軸方向分布荷重によるロールウェブ層のずれの変化を 3 次元的に示したのが図 22(a)-(e), ま た，図22(b)-(e)を $x$ 軸方向から見たのが図 23(a)-(d)である. 図 22(a)\#1000 は巻き取り中, 図 22(b)\#2720 は巻き取 り終了時で， ウェブ層のずれはなく，ロールの側面は平らに巻き取られている．この次の計算ステップからウェ ブに+ $z$ 方向の軸方向分布荷重が作用寸る. 図 22(c)\#2760, (d)\#2783 は, それぞれ $0.8 \mathrm{~g}$ および $1.26 \mathrm{~g}$ の加速度に よる慣性力がロールの軸方向に作用した状態で, それぞれの最外周は最内周 (固着)に対して $z=3.6 \mathrm{~mm}, 12.7 \mathrm{~mm}$, $+z$ 方向へ横ずれしている. 図 22(d)の 1 ステップ後の図 22(e)\#2784では，ロールのウェブ層は $z$ 方向へ大きくず れ，ここで計算が止まる．通常，図 22 (e)のようなロールの層ずれをテレスコープと呼ぶ．計算結果から，(1)テ レスコープ発生時, ロールの外周に近いウェブ層が大きくずれる, (2)ロールの半径方向応力分布はテレスコープ

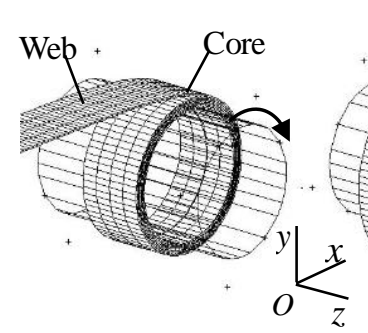

(a) \#1000 Winding

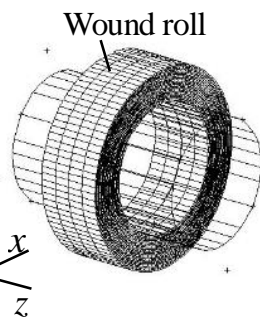

(b) \#2720 End of winding

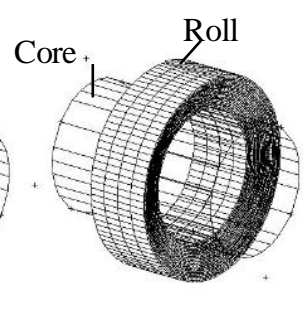

(c) \#2760 Axia acceleration $(0.8 \mathrm{~g})$

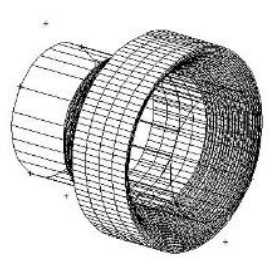

(d) \#2783 (1.26g)

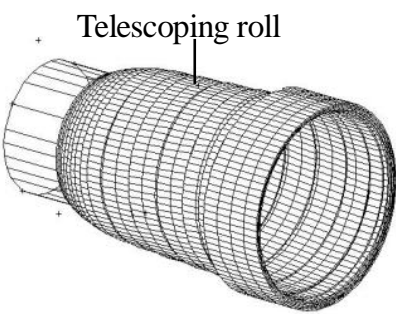

(e) \#2784 (1.28g)

Fig. 22 A series of figures illustrates a development of a telescoping of a roll which is firstly wound correctly and then is subjected to the axial distributed load. The wound web layers slip in the axial direction gradually as the load increases and suddenly they slip largely when the load exceeds a certain value. $\beta=0, \mu=1, T=400 \mathrm{~N} / \mathrm{m}, E=1 \mathrm{GPa}$, and $L=3.32 \mathrm{~m}$. 


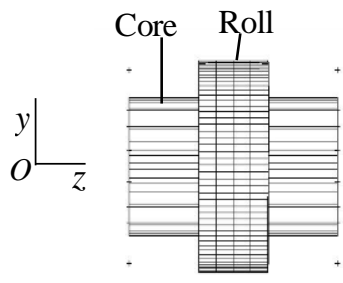

(a) \#2720

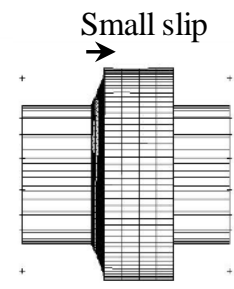

(b) \#2760(0.8g)

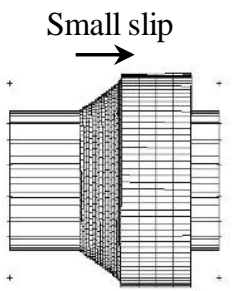

(c) \#2783(1.26g)

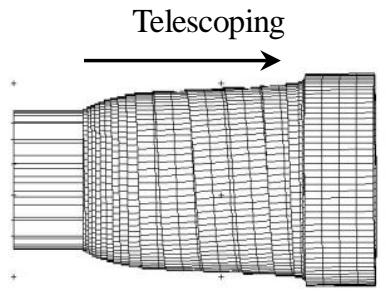

(d) \#2784(1.28g)

Fig. 23 These figures are corresponding to Fig. 22 viewed from $-\mathrm{x}$ direction. The slip of the web layers in the axial direction can be easily observed.

発生直前まであまり大きくは変化しない, (3) ウェブ層間に作用する摩擦力は軸方向荷重が大きくなるとウェブの 中間層で顕著に増大寸ることなどがわかった。

図 22, 23 から, 軸方向加速度の増加とともにウェブ層全体が少しずつずれ, 最後に大きなずれ (テレスコープ) を生じて計算が止まることがわかる．ここではこれをテレスコープ発生限界とした．

テレスコープ発生限界（このときの軸方向加速度）が巻き取り張力 $T$ やウェブの層間摩擦係数 $\mu$ にってどの ように変化するかを調べた．結果を図 24, 25 に示す．両図より，テレスコープ発生限界時の加速度は張力や摩擦 係数とともに増加していることがわかる．このことは，ロールのウェブ層間の摩擦力が大きいほど，テレスコー プ発生限界が高くなると考えられることから, 妥当な結果と思われる.

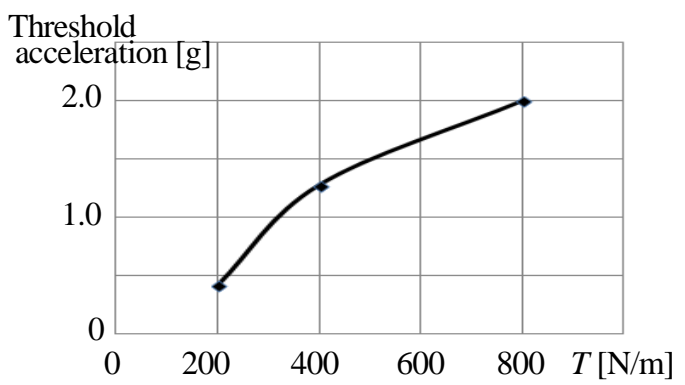

Fig. 24 This figure shows effects of the winding tension on the threshold acceleration, where the telescoping occurs. The threshold increases as the winding tension.

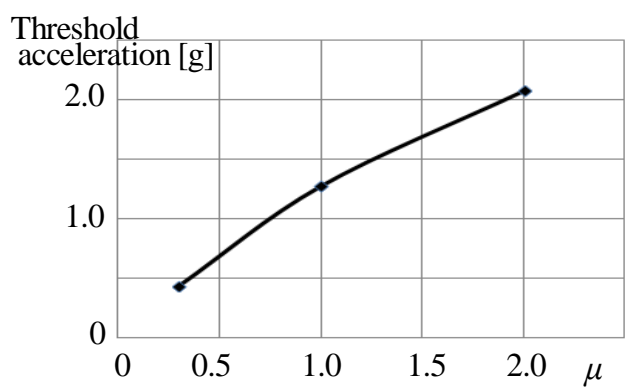

Fig. 25 This figure shows effects of the friction coefficient on the threshold acceleration. The threshold increases as the friction coefficient increases.

\section{4. 結 言}

コアの傾きやウェブの張力分布の不均一に起因するウェブの横ずれとロールの湾弧ならびに層ずれのないよう に巻き取ったあとロールに軸方向荷重を加えることにより生じるテレスコープの発生過程を, FEM 汎用解析ソフ 卜を用いてシミュレーションした. 得られた結果を以下に要約する.

(1)均一な張力分布のもと, コアを傾けてウェブを巻き取った場合, ウェブ後端の幅方向変位を拘束したときは, ウェブはコアの傾きによって緩み側になる方へ横ずれしたあと反転し逆方向へ横ずれしながら巻き取られる．そ の結果, 巻き取られたロールの側面には, コアの傾きで緩み側になる方に凸の緩やかな湾曲が 1 個生じる(湾弧). この特徵はウェブの長さが長くても短くても計算で観察された. また, ウェブ後端の幅方向変位を自由にしたと きは，ウェブは一方向へ横ずれし続けながら巻き取られ，横ずれの反転は生じない，なお，接触するウェブ層は 固着するとして巻き取った場合， ウェブは蛇行しながらコアに巻き取られ，巻き取られたロールの側面に複数の 緩やかな凹凸が生じた（蛇行）。

(2)コアを傾けずに, 不均一な張力分布のもとでウェブを巻き取った場合, ウェブ後端の幅方向変位を拘束したと きは，ウェブは張力が強い側へ緩やかに横ずれしたあと反転して逆方向へ横ずれしながら巻き取られる. その結 
果，巻き取られたロールの側面には，ウェブの張力が大きい側を凸にした湾曲が 1 個生じる (湾弧). ウェブの横 ずれおよびその反転のメカニズムは，不均一な張力分布によるウェブの曲げ変形と曲げ変形したウェブがどのよ うな角度でロールに進入するかによって説明できる. また, ウェブ後端の幅方向変位を自由にしたときは, 張力 分布に不均一があっても，巻き取られたロールの側面は，わずかな外周部を除けば平坦になる.

（3）層ずれのないように巻き取ったロールに軸方向加速度による分布荷重を加えた場合, 加速度の大きさがある 值を越えるとロールのウェブ層に大きなずれ（テレスコープ）が発生する．このときの加速度の大きさは，巻き 取り張力や摩擦係数が大きいほど大きい.

\section{文献}

程輝, 矢鍋重夫, 岩田佳雄, 佐藤秀紀, 小松崎俊彦, 佐藤和恭, クラウニングローラのベルトセンタリング効果,

日本機械学会論文集 C 編, Vol.68, No.674 (2002), pp.2911-2917.

後藤義光, 松原信也, 巻取り欠陥の発生メカニズムと解析例, 精密工学会誌, Vol.78-No.5(2012), pp.377-380.

Lee, C., Kang, H., Kim, H. and Shin, K., Effect of taper tension profile on the telescoping in a winding process of high speed roll to roll printing systems, Journal of Mechanical Science and Technology, 23 (2009), pp.3036-3048.

向井英夫，スリッター・リワインダーの技術読本＼cjkstart増補版 (2005), pp.61-66, 加工技術研究会.

Pfeiffer, J.D., Web guidance concepts and applications, TAPPI Journal, Vol.60, No.12 (1977), pp.53-58.

Smith, R.D., The ultimate roll and web defect troubleshooting guide (2013), TAPPI Press.

矢鍋重夫, 程輝, 野沢泉, ベルトのスキューに関する研究 （第 2 報, パラメータの影響およびスキューのメカニ ズム），日本機械学会論文集 C 編, Vol.67, No.658 (2001), pp.1749-1755.

矢鍋重夫，猪股和博，ローラ搬送されるフィルムのスキューおよびしわ発生のシミュレーション，日本機械学会 論文集 C 編, Vol.73, No.732 (2007), pp.2343-2349.

Yanabe, S., Takahashi, T. and Yamashita, T., Web winding simulation and wound roll stresses, Journal of Advanced Mechanical Design, Systems, and Manufacturing, Vol.4, No.1(2010), pp.281-289. DOI: 10.1299/jamdsm.4.281.

\section{References}

Cheng, H., Yanabe, S., Iwata, Y., Sato, H., Komatsuzaki, T. and Sato, K., Belt centering effects of crowning roller, Transactions of the Japan Society of Mechanical Engineers, Series C, Vol.68, No.674 (2002), pp.2911-2917(in Japanese).

Goto, Y. and Matsubara, S., The mechanism of winding defects and analysed example, Journal of Japan Society of Precision Engineering, Vol.78, No.5 (2012), pp.377-380 (in Japanese).

Lee, C., Kang, H., Kim, H. and Shin, K., Effect of taper tension profile on the telescoping in a winding process of high speed roll to roll printing systems, Journal of Mechanical Science and Technology, 23 (2009), pp.3036-3048.

Mukai, H., Technical book of slitter and rewinder, revised version (2005), pp.61-66, Converting Technical Institute (in Japanese).

Pfeiffer, J.D., Web guidance concepts and applications, TAPPI Journal, Vol.60, No.12 (1977), pp.53-58.

Smith, R.D., The ultimate roll and web defect troubleshooting guide (2013), TAPPI Press.

Yanabe, S., Cheng, H. and Nozawa, I., Study on belt skew (2 ${ }^{\text {nd }}$ report, Effects of parameters and skew mechanism), Transactions of the Japan Society of Mechanical Engineers, Series C, Vol.67, No.658 (2001), pp.1749-1755 (in Japanese).

Yanabe, S. and Inomata, K., Simulation on skew and folded wrinkle of film transferred by misaligned roller, Transactions of the Japan Society of Mechanical Engineers, Series C, Vol.73, No.732 (2007), pp.2343-2349(in Japanese).

Yanabe, S., Takahashi, K. and Yamashita, T., Web winding simulation and wound roll stresses, Journal of Advanced Mechanical Design, Systems, and Manufacturing, Vol.4, No.1(2010), pp.281-289. DOI: 10.1299/jamdsm.4.281. 